\title{
Maturation-dependent modification of the protein phosphorylation profile of isolated goat sperm plasma membrane
}

\author{
D. Nath and G. C. Majumder ${ }^{*}$ \\ Indian Institute of Chemical Biology, Jadavpur, Calcutta 700 032, India
}

\begin{abstract}
Highly purified plasma membranes, isolated by an aqueous two-phase polymer method from goat epididymal spermatozoa, were found to possess a kinase activity that causes phosphorylation of serine and threonine residues of several endogenous plasma membrane proteins. Cyclic AMP, cyclic GMP, $\mathrm{Ca}^{2+}-$ calmodulin, phosphatidylserine-diolein, polyamines and heparin had no appreciable effect on this kinase. Autoradiographic analysis showed that the profile of the phosphorylation of membrane proteins by this endogenous CAMP-independent protein kinase underwent marked modulation during the transit of spermatozoa through the epididymis. In caput sperm plasma membrane, 18, 21, 43, 52, 74 and $90 \mathrm{kDa}$ proteins were phosphorylated, whereas, in the corpus and cauda epididymal spermatozoa, a differential phosphorylation pattern was observed with respect to the $90,74,21$ and 18 $\mathrm{kDa}$ proteins. The rate of phosphorylation of the $74 \mathrm{kDa}$ protein decreased markedly during the early phase of sperm maturation (caput to distal corpus epididymides) whereas there was little change in kinase activity in sperm plasma membrane. In contrast, the rates of phosphorylation of the 18 and $21 \mathrm{kDa}$ proteins increased during the terminal phase (distal corpus to distal cauda epididymides) of sperm maturity, although the kinase activity of membrane decreased significantly during this phase. The modulation of the phosphorylated states of these specific membrane proteins may play an important role in the maturation of epididymal spermatozoa.
\end{abstract}

\section{Introduction}

Spermatozoa undergo maturation by unidentified mechanisms during transit through the epididymis, when they acquire the capacity for forward motility and fertility. Spermatozoa present in the proximal caput epididymidis are immotile. Only as they migrate to the cauda epididymidis do the spermatozoa first acquire the capacity to undergo progressive motility. The sperm surface is believed to play a vital role during this maturation event, although the biochemical identity of the molecules that regulate this process remains unclear (Moore, 1979; Tash and Means, 1983; Parks and Hammerstedt, 1985; Yanagimachi, 1988).

The plasma membranes of mammalian cells possess protein kinases that phosphorylate membrane-associated phosphoproteins (Majumder and Turkington, 1972; Uno et al., 1977; Kang and Chiang, 1986; Boman et al., 1984; Naik et al., 1991; Lytle and Forbush, 1992; Sarrouilhi et al., 1992). Phosphoproteins have been demonstrated in the sperm plasma membrane of humans (Huacuja et al., 1977), cattle (Noland et al., 1984; Chaudhry and Casillas, 1989), hamsters (Devi et al., 1997) and goats (Halder and Majumder, 1986; Mitra and Majumder, 1991). Noland et al. (1984) showed that isolated bovine sperm plasma membrane possesses cyclic

${ }^{*}$ Correspondence.

Received 19 January 1998
AMP-dependent and -independent protein kinases that cause phosphorylation of several membrane-bound proteins. Several lines of evidence support the localization of a cyclic AMP-independent protein kinase (ecto-CIK) on the goat sperm plasma membrane outer surface which causes phosphorylation of multiple membrane-bound phosphoproteins (Mitra and Majumder, 1991; Mitra et al., 1994). Devi et al. (1997) demonstrated an undefined tyrosine kinase in the hamster sperm plasma membrane that phosphorylates primarily the endogenous tyrosine residues of multiple proteins; the phosphorylation profile of some of these proteins are altered significantly during the sperm maturation.

The present study used the isolated plasma membrane from maturing goat epididymal spermatozoa to show the maturation-dependent alteration of membrane protein phosphorylation by the endogenous protein kinases.

\section{Materials and Methods}

The following were obtained from from Sigma Chemical Company (St Louis, MO): ATP (horse muscle); Ficoll-400; SDS molecular weight markers, such as carbonic anhydrase $(29 \mathrm{kDa})$, egg albumin $(45 \mathrm{kDa})$, bovine serum albumin $(66 \mathrm{kDa})$, phosphorylase $\mathrm{b}(97 \mathrm{kDa})$ and $\beta$-galactosidase $(116 \mathrm{kDa})$; casein, dextran (average molecular weight 
229000); polyethyleneglycol compound (average molecular weight 20 000); EGTA (Ethylene glycol bis[ $\beta$-aminoethyl ether]N-N' tetraacetic acid); $O$-phosphoserine; $O$-phosphothreonine; O-phosphotyrosine; phenylmethyl-sulphonyl fluoride (PMSF); and $\beta$-mercaptoethanol. [ ${ }^{32}$ P]orthophosphate (carrier-free) was a product of Bhaba Atomic Research Center, (Trombay, Bombay). $\left[\gamma_{-}{ }^{32} \mathrm{P}\right] \mathrm{ATP}$ was prepared in our laboratory according to the method described by Halder and Majumder (1986).

\section{Isolation of spermatozoa and plasma membrane}

Goat epididymal spermatozoa were isolated within $2 \mathrm{~h}$ of slaughter as described by Rana and Majumder (1987) and Halder et al. (1990). Each part of epididymis was cut into 4-5 pieces with a sharp razor blade and then suspended in a modified Ringer's solution (RPS medium: $119 \mathrm{mmol} \mathrm{NaCl}$ $\mathrm{l}^{-1}, 5 \mathrm{mmol} \mathrm{KCl} \mathrm{l}^{-1}, 1.2 \mathrm{mmol} \mathrm{MgSO}_{4} \mathrm{l}^{-1}, 10 \mathrm{mmol}_{\text {glucose }} \mathrm{l}^{-1}$, $16.3 \mathrm{mmol}$ potassium phosphate $\mathrm{l}^{-1}, 50 \mathrm{U}$ penicillin $\mathrm{ml}^{-1}$, $\mathrm{pH}$ 6.9) with gentle stirring. After $5 \mathrm{~min}$, the suspension was filtered through four layers of cheesecloth and spermatozoa were sedimented by centrifugation at $800 \mathrm{~g}$ for $1 \mathrm{~min}$. The cell pellet was washed twice with RPS medium and finally dispersed in the same medium. Unlike the spermatozoa from the cauda and corpus epididymides, the caput cell preparation contained a large amount of fat globules which were removed by using a discontinuous Ficoll-gradient centrifugation (Halder et al., 1990). The purity of the isolated mature and immature spermatozoa was judged to be high by phase-contrast microscopy and there was no detectable contamination with other cells or cell fragments.

Highly purified plasma membranes were isolated from the mature cauda and maturing corpus and caput spermatozoa by an aqueous two-phase polymer method (Rana and Majumder, 1987, 1989). Membrane purity was judged by estimating marker enzymes (alkaline phosphatase, 5nucleotidase, acrosin, cytochrome C-oxidase, glucose-6phosphatase) and by electron microscopy. The specific activities of the plasma membrane-bound 5-nucleotidase and alkaline phosphatase were 10-14-fold higher in the isolated plasma membrane than in the cell debris, indicating marked membrane enrichment. There was no detectable acrosin or glucose-6-phosphatase in the isolated plasma membrane and the specific activity of cytochrome oxidase was nearly sevenfold lower in membrane than in the cell debris. The data show that there is little contamination of plasma membrane with acrosome, mitochondria and endoplasmic reticulum. The purity of the isolated sperm plasma membrane was shown to be high under the electron microscope. The membrane preparations were finally dispersed in $25 \mathrm{mmol}$ potassium phosphate $\mathrm{1}^{-1}$ buffer, $\mathrm{pH} 7.0$, containing $1 \mathrm{mmol}$ PMSF $1^{-1}, 2$ mmol $\beta$-mercaptoethanol $1^{-1}, 30 \%(\mathrm{v} / \mathrm{v})$ glycerol, and were stored at $-20^{\circ} \mathrm{C}$. The protein content of the plasma membrane was estimated according to the method of Bensadown and Weinstein (1976), using BSA as the standard.

\section{Phosphorylation of sperm plasma membrane proteins}

The rate of phosphorylation of the sperm membrane proteins by the endogenous membrane-bound protein kinase of mature and immature spermatozoa was estimated. The assay medium contained $5 \mathrm{nmol}\left[\gamma^{32} \mathrm{P}\right]$ ATP (containing 8-10 $\times 10^{6}$ c.p.m.), $2 \mu \mathrm{mol} \mathrm{MgCl}_{2} 1^{-1}, 0.2 \mu \mathrm{mol}$ EGTA $\mathrm{l}^{-1}$ and $150-200 \mu \mathrm{g}$ isolated plasma membrane in a total volume of $0.2 \mathrm{ml} 50 \mathrm{mmol}$ Tris- $\mathrm{HCl} \mathrm{1}{ }^{-1}, \mathrm{pH} 8.5$. The reaction mixture was incubated for $1 \mathrm{~min}$ at $37^{\circ} \mathrm{C}$; the reaction was stopped with $5 \mathrm{ml} 10 \%(\mathrm{w} / \mathrm{v})$ trichloroacetic acid (TCA); and the resulting protein precipitate was filtered through a Whatman No.1 filter paper disc and then washed with $40 \mathrm{ml}$ $5 \%(\mathrm{w} / \mathrm{v})$ TCA. The amount of $\left[{ }^{32} \mathrm{P}\right]$ activity in the disc was determined in a liquid scintillation spectrometer (Beckman LS 1800) as described by Halder and Majumder (1986).

\section{Autoradiography of ${ }^{32} \mathrm{P}$-labelled membrane proteins}

The ${ }^{32}$ P-labelled protein precipitates collected by centrifugation were washed first with $5 \%(\mathrm{w} / \mathrm{v}) \mathrm{TCA}$, and then with diethyl ether to remove the TCA. Finally, the ${ }^{32} \mathrm{P}$-labelled proteins were dissolved in SDS-PAGE reducing sample buffer (Laemmli, 1970) and the suspended materials were removed by centrifugation. The protein contents of supernatants were estimated by Bensadown and Weinstein (1976). The labelled proteins were subjected to $10 \%$ SDS-polyacrylamide gel electrophoresis. Approximately $250 \mu \mathrm{g}$ protein was loaded in each lane of the gel $(12 \mathrm{~cm} \times 14 \mathrm{~cm} \times 1.5 \mathrm{~mm})$. Electrophoresis was carried out for approximately $3.5 \mathrm{~h}$ with a constant current of $25 \mathrm{~mA}$ per gel using bromophenol blue as a tracking dye. After completion of the run, the gel was fixed as well as stained in $0.25 \%(\mathrm{w} / \mathrm{v})$ Coomassie blue stain in acetic acid: methanol: $\mathrm{H}_{2} \mathrm{O}(4.0: 0.8: 5.2)(\mathrm{v} / \mathrm{v})$ for $20 \mathrm{~min}$ and destained in methanol:acetic acid: $\mathrm{H}_{2} \mathrm{O}(4.00: 0.75: 5.20)(\mathrm{v} / \mathrm{v})$ for $2 \mathrm{~h}$ at $37^{\circ} \mathrm{C}$. The gel was dried in an electric gel drier at $80^{\circ} \mathrm{C}$ for $2 \mathrm{~h}$. After drying, the gel was autoradiographed, then analysed with a LKB-2202 ultrascan laser densitometer at $632 \mathrm{~nm}$.

The marker proteins were $\beta$-galactosidase $(116 \mathrm{kDa})$, phosphorylase b $(97 \mathrm{kDa})$, egg albumin $(45 \mathrm{kDa}), \mathrm{BSA}$ $(66 \mathrm{kDa})$ and carbonic anhydrase $(29 \mathrm{kDa})$.

\section{Estimation of sperm plasma membrane cAMP-independent protein kinase activity}

The cyclic AMP-independent protein kinase (CIK) activity of the isolated maturing (caput, corpus) and mature (cauda) sperm plasma membranes were estimated using casein as the exogenous substrate. The reaction mixture contained $1 \mathrm{mg}$ casein, 200 nmoles $\left[\gamma^{-32}\right.$ P]ATP containing 3-6 $\times 10^{7}$ c.p.m., $2 \mu \mathrm{mol} \mathrm{MgCl}_{2} \mathrm{l}^{-1}$ and $50-100 \mu \mathrm{g}$ isolated plasma membrane proteins in a total volume of $0.2 \mathrm{ml} 50 \mathrm{mmol}$ Tris- $-\mathrm{HCl}^{-1}$ buffer, $\mathrm{pH} 8.5$. The incubation was carried out at $37^{\circ} \mathrm{C}$ for $5 \mathrm{~min}$ and the reaction was stopped with the addition of $0.1 \mathrm{ml}$ of $0.5 \%(\mathrm{w} / \mathrm{v})$ casein containing $250 \mathrm{mmol}$

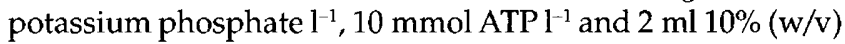
TCA. The resulting protein precipitates were washed with $40 \mathrm{ml} 5 \%(\mathrm{w} / \mathrm{v})$ TCA and processed for assay of ${ }^{32} \mathrm{P}$ radioactivity as described above. One unit of the CIK activity has been defined as the amount of the enzyme that catalyses the transfer of 10 pmole ${ }^{32} \mathrm{P}$ from $\left[\gamma^{-32} \mathrm{P}\right] \mathrm{ATP}$ to casein. 


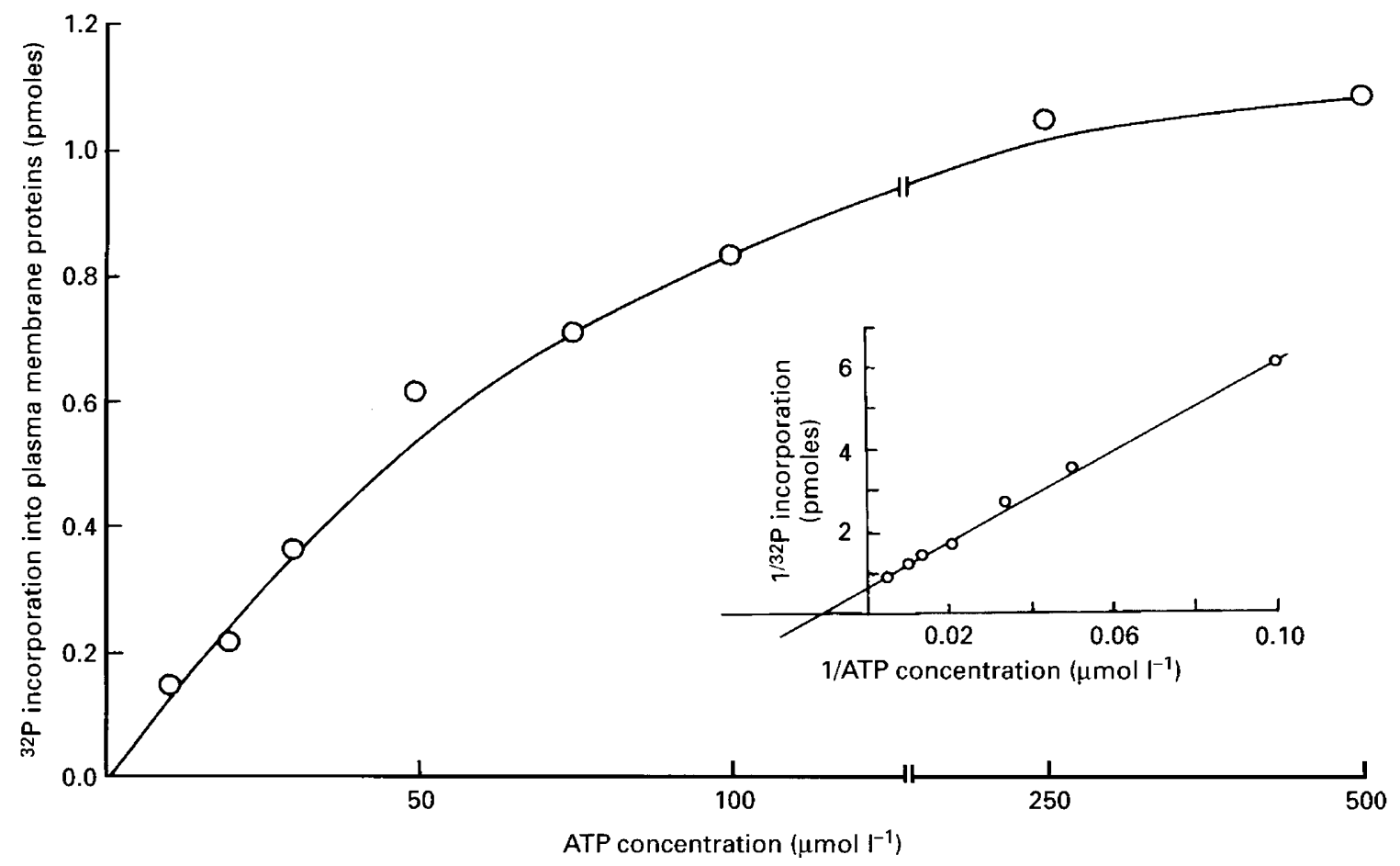

Fig. 1. Effect of ATP concentration on the phosphorylation of endogenous goat sperm proteins by plasma membrane kinase. Standard assay conditions were used, except for the variation of the amount of ATP. The inset shows the Lineweaver-Burk plot of these data. These data are representative of five experiments.

\section{Phospho-amino acid analysis}

Plasma membrane proteins (as endogenous substrates) were phosphorylated under the standard assay conditions and the nature of phospho-amino acid(s) was analysed using the method of Cooper et al. (1983). The ${ }^{32}$ P-labelled proteins were precipitated with $15 \%(\mathrm{w} / \mathrm{v})$ TCA. The precipitate was washed three times with 1:1 (v/v) acetone:diethyl ether, dried and hydrolysed in $0.5 \mathrm{ml} 6 \mathrm{~mol} \mathrm{HCl} 1^{-1}$ at $110^{\circ} \mathrm{C}$ for $4 \mathrm{~h}$. The hydrolysate was dried and dissolved in $0.1 \mathrm{ml}$ formic acid:acetic acid: $\mathrm{H}_{2} \mathrm{O}$ (25:78:897 by volume), $\mathrm{pH} 1.9$. The samples $(50 \mu l)$ were mixed with authentic international standards (phosphoserine, phosphothreonine and phosphotyrosine) and applied to the cathode edge of a cellulose thin layer sheet and electrophoresis was performed at $450 \mathrm{~V}$ for $90 \mathrm{~min}$ in a $\mathrm{pH} 3.5$ buffer system (acetic acid: pyridine: $\mathrm{H}_{2} \mathrm{O} ; 50: 5: 945$ by volume). Radioactive spots were located by autoradiography whereas, for the detection of the phospho-amino acid markers, the plates were sprayed with $0.4 \%(\mathrm{w} / \mathrm{v})$ ninhydrin reagent and the colour spots were developed by heating the plate at $40^{\circ} \mathrm{C}$ for $20 \mathrm{~min}$.

\section{Results}

\section{Characterization of membrane protein phosphorylation by the endogenous protein kinase of the isolated sperm plasma membrane}

There was a linear increase in the rate of protein phosphorylation with the increase of membrane protein concentration in the assay. This proportional increase was observed up to $200 \mu \mathrm{g}$ plasma membrane protein per assay. The amount of $\left[{ }^{32} \mathrm{P}\right]$ incorporated into the protein was approximately 1 pmole per $100 \mu \mathrm{g}$ protein (average of ten experiments; range 0.91-1.25 pmole). These results demonstrated that a protein kinase is bound to the purified sperm plasma membrane that causes phosphorylation of the endogenous membrane proteins. The rate of phosphorylation of plasma membrane-bound proteins increases with increasing concentration of $\left[\gamma^{32} \mathrm{P}\right] \mathrm{ATP}$ (Fig. 1). The apparent $K_{\mathrm{m}}$ value of the plasma membrane protein kinase for ATP (as estimated by the inverse plot of the data) was 80 $\pm 10 \mu \mathrm{mol} \mathrm{l}^{-1}$ (Fig. 1). There was little phosphorylation of membrane proteins when $\left[\gamma^{32} \mathrm{P}\right] \mathrm{GTP}$ was the donor of $\left[{ }^{32} \mathrm{P}\right]$ (Table 1, Expt 1). The effect of excess unlabelled nucleotides like ATP and GTP ( $1 \mathrm{mmol} \mathrm{l}^{-1}$ and $5 \mathrm{mmol} \mathrm{l}^{-1}$, respectively) on the incorporation of $\left.{ }^{32} \mathrm{P}\right]$ into the membrane-bound proteins was determined (Table 1, Expt 2). The incorporation of $\left.{ }^{32} \mathrm{P}\right]$ was inhibited to a great extent (approximately 95\%) by the unlabelled ATP $\left(5 \mathrm{mmol} \mathrm{l}^{-1}\right)$ whereas GTP had no appreciable effect. The data demonstrate that GTP cannot compete with ATP in donating terminal phosphate for phosphorylation of sperm membrane-bound proteins. The effects of a variety of reagents on the plasma membranebound kinase activity were investigated to gain an insight into its enzymic characteristics (Table 2). The omission of $\mathrm{Mg}^{2+}$ from the assay system reduced the kinase activities markedly (by approximately 90\%). EDTA $\left(2 \mathrm{mmol} \mathrm{l}^{-1}\right)$ inhibited nearly completely the membrane protein phosphorylation reaction. The kinase activities of the membrane are dependent on a bivalent metal ion, such as $\mathrm{Mg}^{2+}, \mathrm{Mn}^{2+}$ or $\mathrm{Co}^{2+}$; the degree of activation was greatest in 
Table 1. Protein phosphorylation of goat sperm plasma membrane in presence of GTP

\begin{tabular}{|c|c|c|}
\hline & Nucleotides & $\begin{array}{l}\left.{ }^{2} \mathrm{P}\right] \text { incorporated into plasma membrane } \\
\text { proteins (pmoles) }(\text { mean } \pm \mathrm{SD})\end{array}$ \\
\hline \multirow[t]{2}{*}{ Expt 1} & {$\left[\gamma^{32} \mathrm{P}\right] \mathrm{ATP}$} & $10.2 \pm 0.01$ \\
\hline & {$\left[\gamma^{32}\right.$ P]GTP } & $0.4 \pm 0.05$ \\
\hline \multirow[t]{5}{*}{ Expt 2} & {$\left[\gamma^{32} \mathrm{P}\right] \mathrm{ATP}$} & $10.4 \pm 0.02$ \\
\hline & $+\operatorname{GTP}\left(1 \mathrm{mmol} \mathrm{l}^{-1}\right)$ & $10.3 \pm 0.01$ \\
\hline & $+\operatorname{GTP}\left(5 \mathrm{mmol} \mathrm{l}^{-1}\right)$ & $10.0 \pm 0.03$ \\
\hline & $+\operatorname{ATP}\left(1 \mathrm{mmol} \mathrm{l}^{-1}\right)$ & $1.81 \pm 0.25$ \\
\hline & $+\operatorname{ATP}\left(5 \mathrm{mmol} \mathrm{l}^{-1}\right)$ & $0.49 \pm 0.10$ \\
\hline
\end{tabular}

Expt 1: plasma membrane was incubated as in standard assay conditions, except that $\left[\gamma^{-32} \mathrm{P}\right] \mathrm{ATP}$ was replaced by $\left[\gamma^{-32} \mathrm{P}\right] \mathrm{GTP}$ in one set of tubes. Expt 2 : plasma membrane was incubated under standard assay conditions with or without the specified amount of non-radioactive nucleotides. All the data shown are from five experiments.

the presence of $\mathrm{Mg}^{2+}$, whereas $\mathrm{Ca}^{2+}\left(1 \mathrm{mmol} \mathrm{l}^{-1}\right)$ completely inhibits the enzyme. The apparent $K_{\mathrm{m}}$ value of the enzyme for $\mathrm{Mg}^{2+}$ is $5 \pm 2 \mathrm{mmol} \mathrm{l}^{-1}$ (Fig. 2). Calmodulin (10 $\mu \mathrm{g}$ ), an activator of the $\mathrm{Ca}^{2+}$-calmodulin-dependent protein kinase (McGuinness et al., 1985), polyamines like spermine, spermidine and putricine $\left(2 \mathrm{mmol} \mathrm{l} \mathrm{l}^{-1}\right)$, known to be activators of casein kinase II and heparin $\left(10 \mu \mathrm{g} \mathrm{ml}^{-1}\right)$, and inhibitor of casein kinase II (Chaudhry and Casillas, 1989), had no appreciable affect on the rate of protein phosphorylation. Cyclic AMP $\left(5 \mu_{\mathrm{mol} \mathrm{1}}^{-1}\right)$, cyclic AMPdependent protein kinase (protein kinase A) activator, cyclic GMP $\left(5 \mu \mathrm{mol} \mathrm{l}^{-1}\right)$, activator of protein kinase $\mathrm{G}$, activator of protein kinase $C$ (phosphatidylserine) $\left(25 \mu \mathrm{g} \mathrm{ml}^{-1}\right)$ and diolein $\left(10 \mu \mathrm{g} \mathrm{ml}^{-1}\right)$ (Nishizuka, 1984) had no significant effect on the phosphorylation reaction (Table 2 ). These results indicate that the sperm plasma membrane-bound kinase is a cyclic AMP-independent enzyme with enzymic properties different from those of protein kinase A, C, G, casein kinase II and $\mathrm{Ca}^{2+}$-calmodulin dependent protein kinase.

The ${ }^{32} \mathrm{P}$-labelled membrane proteins were treated with hydroxylamine and $1 \mathrm{~mol} \mathrm{NaOH} \mathrm{l^{-1 }}$ to test the chemical nature of the bond linking [ $\left.{ }^{32} \mathrm{P}\right] \mathrm{Pi}$ to the proteins (Table 3). ${ }^{32} \mathrm{P}$-labelled protein lost almost $100 \%$ of its radioactivity

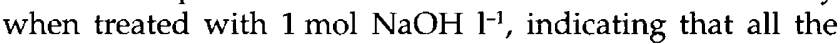
radioactivity of the ${ }^{32} \mathrm{P}$-labelled sperm proteins is associated with alkali-labile phosphoester bonds. Hydroxylamine treatment had no effect on the ${ }^{32} \mathrm{P}$-radioactivity of the membrane proteins. The insensitivity of the incorporation into hydroxylamine rules out an acylphosphate linkage (Table 3). Amino acid analysis of sperm plasma membrane ${ }^{32} \mathrm{P}$-labelled phosphoproteins showed that the protein kinase causes phosphorylation of both the serine and threonine residues of the phosphoproteins, the amount of phosphorylation of serine was much higher (approximately threefold) than that of threonine (Fig. 3). The sperm plasma membrane kinase did not cause phosphorylation of tyrosine residues of the plasma membrane proteins.

\section{Protein phosphorylation during epididymal maturation}

The phosphorylation profiles in isolated plasma membranes of different maturing and mature spermatozoa were studied to investigate the physiological role of plasma membrane phosphoproteins in sperm maturation. The immature caput sperm plasma membrane showed a

Table 2. Effect of various reagents on the phosphorylation of goat sperm plasma membrane proteins by the endogenous protein kinase

\begin{tabular}{|c|c|c|}
\hline & Systems & $\begin{array}{l}\text { Incorporation of }\left[{ }^{32} \mathrm{P}\right] \text { into } \\
\text { proteins }(\% \text { control })\end{array}$ \\
\hline Expt 1 & $\begin{array}{l}\text { Control } \\
-\mathrm{Mg}^{2+} \\
-\mathrm{Mg}^{2+}+\mathrm{EDTA}\left(2 \mathrm{mmol}^{-1}\right) \\
-\mathrm{Mg}^{2+}+\mathrm{MgCl}_{2}\left(1 \mathrm{mmoll}^{-1}\right) \\
-\mathrm{Mg}^{2+}+\mathrm{MgCl}_{2}\left(5 \mathrm{mmol} \mathrm{l}^{-1}\right) \\
-\mathrm{Mg}^{2+}+\mathrm{CoCl}_{2}\left(1 \mathrm{mmol} \mathrm{l}^{-1}\right) \\
-\mathrm{Mg}^{2+}+\mathrm{CoCl}_{2}\left(5 \mathrm{mmol} \mathrm{l}^{-1}\right) \\
-\mathrm{Mg}^{2+}+\mathrm{MnCl}_{2}\left(5 \mathrm{mmol} \mathrm{l}^{-1}\right) \\
-\mathrm{Mg}^{2+}+\mathrm{CaCl}_{2}\left(0.5 \mathrm{mmol} \mathrm{l}^{-1}\right)\end{array}$ & $\begin{aligned} 100 & \\
10.50 & \pm 1.12 \\
1.0 & \pm 0.1 \\
45 & \pm 2 \\
100.00 & \pm 0.32 \\
51.0 & \pm 3.0 \\
60.0 & \pm 1.1 \\
35.0 & \pm 2.0 \\
0.0 & \end{aligned}$ \\
\hline Expt 2 & 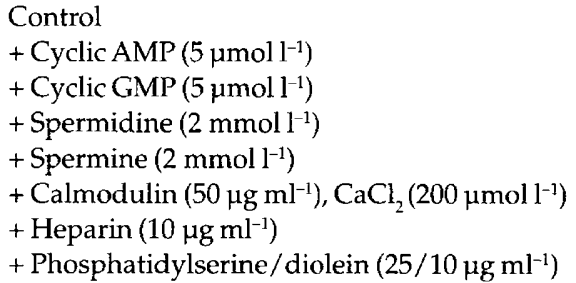 & $\begin{aligned} 100 & \\
105 & \pm 1 \\
96 & \pm 4 \\
96 & \pm 2 \\
91 & \pm 4 \\
92 & \pm 5 \\
94 & \pm 8 \\
102 & \pm 2\end{aligned}$ \\
\hline
\end{tabular}

Expt 1: isolated plasma membrane was washed thoroughly in a modified Ringer's solution medium without $\mathrm{MgCl}_{2}$. Standard assay conditions were used, except for the addition or omission indicated. The control assay system contained all the reagents as defined in standard assay conditions. Expt 2: the protein phosphorylation reaction was studied under standard assay conditions except for the specified additions. Values are mean $\pm \mathrm{s}$ and are representative of four experiments. 
Table 3. Alkali-labile phosphoester bonds of [32 P]-labelled protein of goat sperm plasma membrane

\begin{tabular}{lc}
\hline Treatment & $\begin{array}{c}\text { Incorporation of }\left[{ }^{32} \mathrm{P}\right] \text { into } \\
\text { protein }\left(\mathrm{pmol} \mathrm{m}^{-1}\right)\end{array}$ \\
\hline Control & $10.05 \pm 0.43$ \\
Hydroxylamine $\left(0.8 \mathrm{~mol} \mathrm{l}^{-1}\right)$ & $9.86 \pm 1.2$ \\
$\mathrm{NaCl}\left(0.6 \mathrm{~mol} \mathrm{l}^{-1}\right)$ & $10.22 \pm 0.49$ \\
$\mathrm{NaOH}\left(1 \mathrm{~mol} \mathrm{l}^{-1}\right)$ & $0.32 \pm 0.1$ \\
\hline
\end{tabular}

Sperm membrane proteins were phosphorylated by incubating the isolated plasma membrane with [ $\left.{ }^{32} \mathrm{P}\right]$ ATP. The trichloroacetic acid (TCA) precipitates of the labelled proteins were subjected to the specified treatments. The ${ }^{32} \mathrm{P}$-labelled protein precipitates from the untreated 'control' tubes were washed with $5 \%(\mathrm{w} / \mathrm{v})$ TCA. The labelled protein precipitates of another set of tubes were solubilized in $1 \mathrm{~mol} \mathrm{NaOH}^{-1}$ and heated in a boiling waterbath for $15 \mathrm{~min}$ (Kinzel and Mueller, 1973). The cooled tubes were treated with $40 \%(w / v)$ TCA to precipitate proteins that were processed for assay of radioactivity. Hydroxylamine treatment was performed according to the method of Hokin et al. (1965). The precipitate was washed once with water and suspended in either $0.8 \mathrm{~mol}^{2}$ hydroxylamine $\mathrm{l}^{-1}$ or $0.6 \mathrm{~mol} \mathrm{NaCll}^{-1}$ for the control and incubated at $37^{\circ} \mathrm{C}$ for $15 \mathrm{~min}$. The reaction was terminated with ice-cold $40 \%(\mathrm{w} / \mathrm{v}) \mathrm{TCA}$. The precipitate was processed for the assay of $\left[{ }^{32} \mathrm{P}\right]$ radioactivity. Values are mean $\pm \mathrm{SD}$ from three experiments.

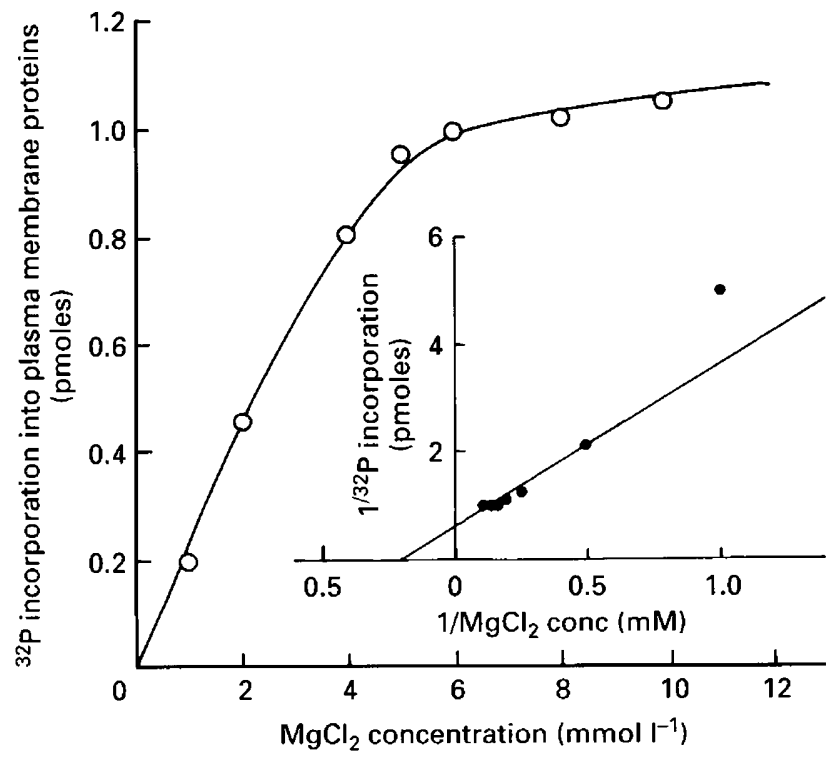

Fig. 2. Effect of $\mathrm{MgCl}_{2}$ concentration on the phosphorylation of goat plasma membrane proteins. Standard assay conditions were used except for the variation in the amount of $\mathrm{MgCl}_{2}$. These data are representative of three experiments.

significantly higher rate of phosphorylation of proteins than did the mature cauda sperm plasma membrane (Fig. 4). There was a gradual decrease in the rate of phosphorylation in sperm plasma membrane from the caput to distal cauda epididymides. The rate of membrane protein phosphorylation decreased to 25,40 and $55 \%$ as the caput spermatozoa pass through the distal corpus, proximal cauda

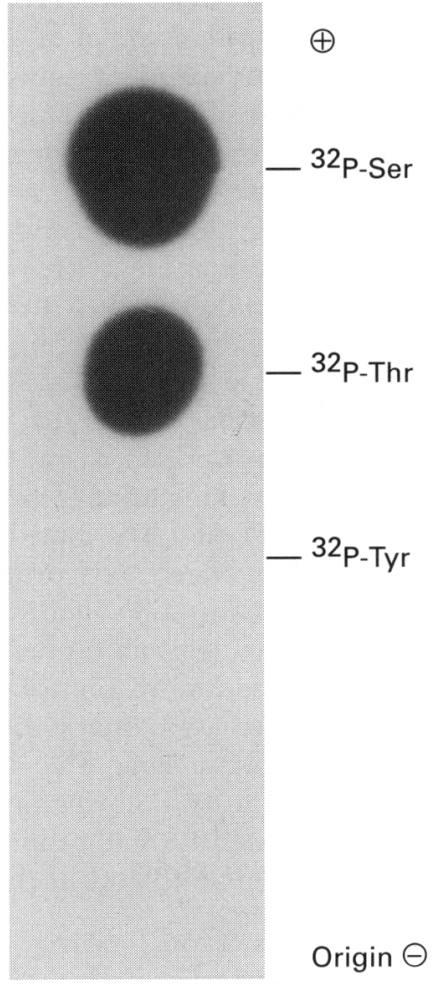

Fig. 3. Identification of the phosphorylated amino acids in goat plasma membrane phosphoproteins. The ${ }^{32} \mathrm{P}$-labelled plasma membrane proteins were hydrolysed and ${ }^{32} \mathrm{P}$-labelled amino acids were analysed by cellulose thin-layer electrophoresis. ${ }^{32} \mathrm{P}$-labelled amino acids were detected by autoradiography. The position of the authentic internal standard are indicated as ${ }^{32} \mathrm{P}-\mathrm{Ser}$, phosphoserine; ${ }^{32} \mathrm{P}-\mathrm{Thr}$, phosphothreonine; and ${ }^{32} \mathrm{P}-\mathrm{Tyr}$, phosphotyrosine. The ${ }^{32} \mathrm{P}$-labelled phosphoamino acid spots were cut out and analysed for radioactivity in a scintillation spectrometer. The radioactivity associated with the P-serine and P-threonine spots were 5502 and 1890 c.p.m., respectively.

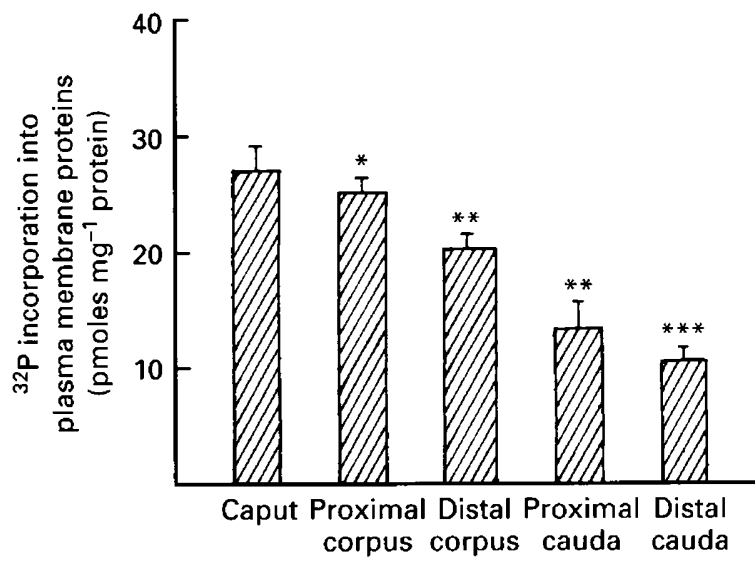

Fig. 4. Phosphorylation of goat plasma membrane proteins by endogenous protein kinase of isolated goat sperm plasma membrane during epididymal maturation. Standard assay conditions were used except for the difference in the plasma membrane preparation. Values are mean \pm SEM of five experiments. Data were analysed by Student's $t$ test. *Not significant; ${ }^{* *} P<0.01$; ${ }_{* * *} P<0.001$ versus caput sperm membrane. 
and distal cauda epididymides, respectively. The data show that the sperm membrane proteins are phosphorylated by an endogenous cyclic AMP-independent protein kinase and that the protein phosphorylation profile undergoes a significant decrease during epididymal sperm maturation.

${ }^{32} \mathrm{P}$-labelled phosphoproteins of the maturing sperm membranes were resolved by SDS-PAGE and the radioactive bands were detected by autoradiography (Fig. 5). These bands were analysed and scanned with an LKB 2202 ultrascan laser densitometer at $632 \mathrm{~nm}$ (Fig. 6). Fine welldefined bands were detected in the autoradiogram of the immature caput sperm plasma membrane. The molecular masses of these proteins are 18,21, 43, 52 and $74 \mathrm{kDa}$. During sperm maturation, there was a remarkable modulation of the protein phosphorylation profile. The rate of phosphorylation of the $74 \mathrm{kDa}$ protein decreased progressively as a consequence of sperm maturation and, in the cauda spermatozoa, there was no detectable phosphorylation of this protein. In contrast, the rate of phosphorylation of 18 and $21 \mathrm{kDa}$ proteins increased markedly during the epididymal transit of spermatozoa. The 43 and $52 \mathrm{kDa}$ phosphoproteins showed rather a slower rate of change of phosphorylation during sperm maturation. The $52 \mathrm{kDa}$ protein was the most prominent band in the caput sperm

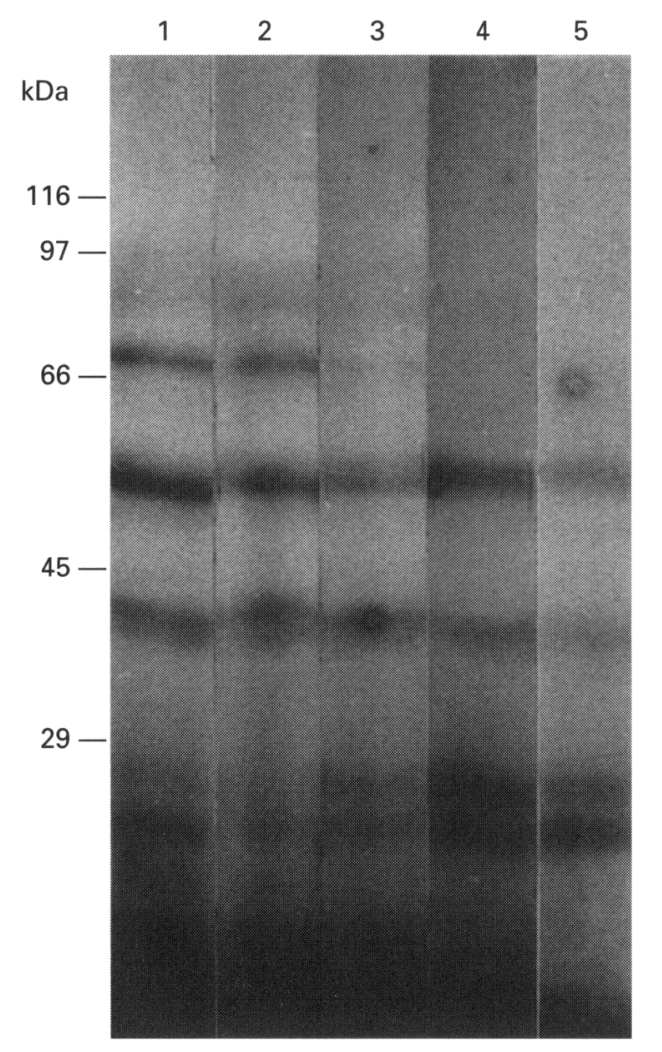

Fig. 5. Autoradiography of maturing epididymal goat sperm membrane ${ }^{32} \mathrm{P}$-labelled proteins. Lane 1 , caput plasma membrane; lane 2, proximal corpus plasma membrane; lane 3, distal corpus; lane 4, proximal cauda; lane 5, distal cauda. Phosphorylation of isolated plasma membrane was performed under standard assay conditions. Approximately $250 \mu \mathrm{g}{ }^{32} \mathrm{P}$-labelled proteins was loaded in each lane. plasma membrane, whereas the $18 \mathrm{kDa}$ protein was the most prominent band in the cauda sperm plasma membrane. A minor ${ }^{32} \mathrm{P}$-labelled protein $(90 \mathrm{kDa})$ was detected in the caput sperm plasma membrane. The rate of phosphorylation of this protein decreased considerably during maturation, and the bands were not detectable in the distal corpus to cauda epididymides. The protein bands below $18 \mathrm{kDa}$ were not well defined, although the amount of radioactivity associated with these proteins was high, particularly in the immature sperm plasma membrane.

\section{Studies on maturing sperm plasma membrane-bound protein kinase}

The membrane-bound kinase activity of the isolated sperm membrane was measured using casein as the protein substrate (Fig. 7). The specific activity of the kinase was similar in the caput, proximal and distal corpus sperm membrane but, subsequently, decreased markedly during sperm maturation; the enzyme concentration was lowest in the distal cauda sperm membrane. During the maturation process, there was an approximately threefold decrease in the specific activity of the kinase.

\section{Discussion}

Previous studies from our laboratory have provided several lines of evidence to support the localization of cyclic AMPdependent and -independent protein kinases on the external surface of the intact mature goat spermatozoa plasma membrane (Halder et al., 1986; Dey and Majumder, 1990). The ecto-CIK of viable spermatozoa has high affinity for the phosphorylation of the serine and threonine residues of multiple ecto-phosphoproteins (Halder and Majumder, 1986; Halder et al., 1986). The present study showed that highly purified plasma membrane isolated from the goat cauda epididymidal spermatozoa possesses CIK that phosphorylates several membrane-bound phosphoproteins. The phosphorylation of the membrane proteins is not dependent on the endogenous cyclic AMP-dependent protein kinase since addition of cyclic AMP had no effect on the rate of protein phosphorylation. The results of the present study are consistent with the earlier observation that the goat sperm ecto-cyclic AMP-dependent kinase is incapable of phosphorylating the sperm surface ecto-phosphoproteins (Dey and Majumder, 1990). The isolated plasma membrane of mature bovine spermatozoa possesses both the cyclic AMP-dependent and -independent protein kinase but, unlike those in the isolated plasma membrane of mature goat spermatozoa, both these membrane-bound kinases are capable of phosphorylating several endogenous phosphoproteins (Noland et al., 1984). The biochemical basis for the different behaviour of goat and bovine sperm plasma membranes, is not clear. It is possible that goat sperm membrane does not possess substrate proteins for the cyclic AMP-dependent protein kinase. 

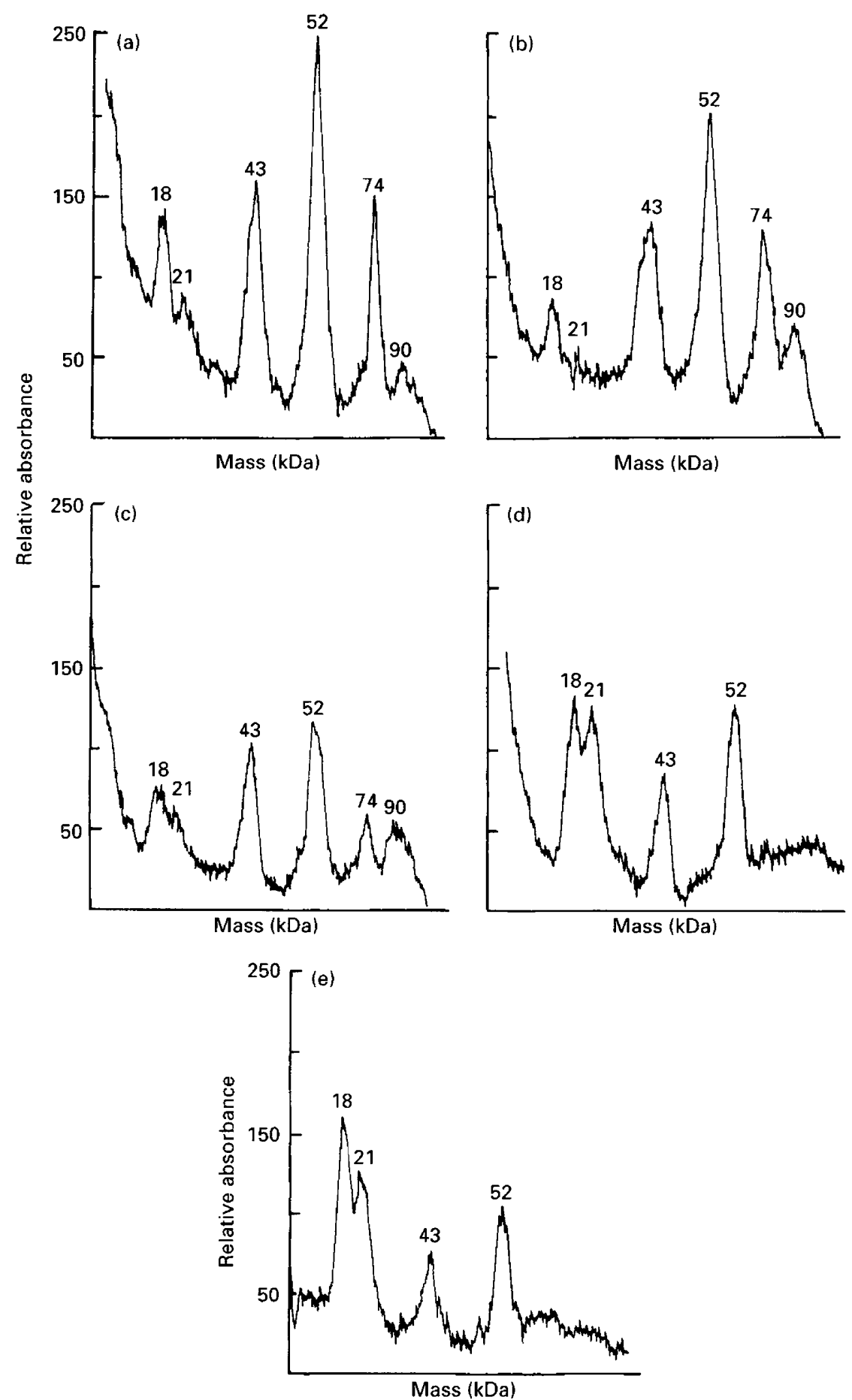

Fig. 6. Relative absorbance of labelled proteins from goat sperm plasma membrane at $630 \mathrm{~nm}$ using LKB-2202 ultrascan laser densitometer. The major phosphoprotein bands are shown as numerals (kDa) in the figure. (a) Caput sperm plasma membrane; (b) proximal corpus sperm plasma membrane; (c) distal corpus sperm plasma membrane; (d) proximal cauda sperm plasma membrane; (e) distal cauda sperm plasma membrane.

Although phosphoproteins and protein kinases have been detected in the plasma membranes of several mammalian species (Noland et al., 1984; Halder and Majumder, 1986; Chaudhry and Casillas, 1989; Devi et al., 1997), the profiles of the membrane protein phosphorylation and the endogenous kinases during epididymal sperm maturation are largely unknown. Our preliminary studies with goat spermatozoa showed that the immature caput spermatozoa have 


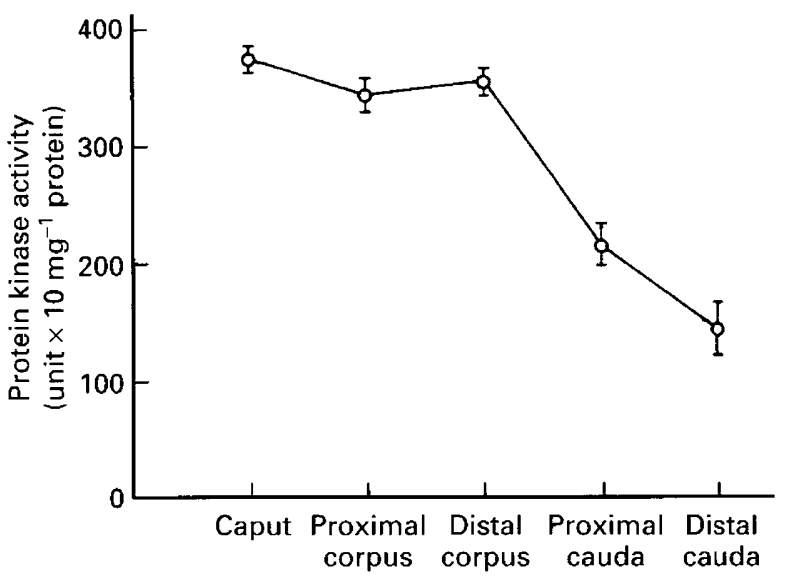

Fig. 7. The cAMP-independent protein kinase activity of isolated goat sperm plasma membrane during epididymal maturation. The activities were estimated in the standard assay conditions using casein as the exogenous substrate. Values are mean \pm SEM for six experiments. Data were analysed by Student's $t$ test. The cAMPindependent protein kinase activity of proximal corpus sperm plasma membrane $(P<0.05)$, proximal and cauda sperm plasma membrane $(P<0.001)$ was significantly lower than that in the caput sperm plasma membrane.

significantly higher rates of ecto-protein phosphorylation by the endogenous protein kinase than do mature cauda spermatozoa (Mitra and Majumder, 1991).

The present study using the isolated membrane model has analysed, for the first time, the maturational profiles of membrane-associated phosphoproteins and the protein kinase activity at various stages of epididymal sperm transit. The data show that the profile of the phosphorylation of membrane proteins by the endogenous CIK undergoes marked modulation during sperm transit through the epididymis. The rate of phosphorylation of the $74 \mathrm{kDa}$ protein decreases markedly during the early phase (caput to distal corpus epididymides) of sperm maturation, when there is little change in CIK activity in plasma membrane, suggesting that the observed decrease in the phosphorylation of this protein is due to the restricted availability of proteins for the action of the kinase in the maturing sperm membrane. In contrast, the rates of phosphorylation of the 18 and $21 \mathrm{kDa}$ proteins increase significantly during the terminal phase (distal corpus to distal cauda epididymides) of sperm maturation, although the kinase activity of the membrane decreases markedly at this stage. The data suggest a greater availability of these substrate proteins in the sperm plasma membrane at the last phase of sperm maturation. Studies from our laboratory show that the 74, 52, 21 and $18 \mathrm{kDa}$ proteins of the sperm plasma membrane serve as substrates for the purified CIK (D. Nath and G. C. Majumder, unpublished). Thus, CIK appears to be primarily responsible for the maturationdependent alteration of membrane phosphoproteins. The biochemical basis of this maturation-dependent decrease in CIK activity and the rate of phosphorylation are not clear. There may be some conformational changes during the epididymal maturation event that result in a lower rate of kinase activity in addition to membrane protein phosphorylation.

Sea urchin plasma membrane has been shown to contain a $160 \mathrm{kDa}$ phosphoprotein that undergoes dephosphorylation when the spermatozoon comes into contact with the egg jelly, and this membrane-bound phosphoprotein may have a role in fertilization (Ward and Vacquier, 1983). Goat spermatozoa have been shown to possess a coupled-enzyme system, consisting of a CIK and a phosphoprotein phosphatase, that determines the phosphorylated states of the cell surface phosphoproteins by protein phosphorylation-dephosphorylation (Barua et al., 1990). These ectoenzymes and their protein substrates may have an important role in the regulation of the forward motility of spermatozoa (Halder and Majumder, 1986; Halder et al., 1986; Barua et al., 1990). The present study defines specific membraneassociated phosphoproteins, in which the phosphorylation status undergoes profound manipulation as a consequence of epididymal sperm maturation. Forward motility was initiated in goat spermatozoa during transit through the distal corpus epididymidis, and these cells acquire maximum motility as they reach the distal cauda epididymidis (Banerjee et al., 1992). In the present study in goats, there was a marked increase in the phosphorylation of the 18 and $21 \mathrm{kDa}$ proteins and in the dephosphorylation of the $74 \mathrm{kDa}$ protein during the terminal phase of epididymal sperm transit (distal corpus to distal cauda). The close correlation of initiation of motility and membrane protein phosphorylation modulation suggests that these specific membrane proteins play a vital role in epididymal sperm maturation.

The authors wish to thank M. Barua and other members of this laboratory for helpful discussion and comments. We are also thankful to the Director, J. Das for his interest in this study. The research fellowship offered to D. Nath by the Indian Council Of Medical Research and the Council Of Scientific and Industrial Research is gratefully acknowledged.

\section{References}

Banerjee S, Dey N and Majumder GC (1992) Maturation-dependent goat epididymal sperm autoagglutination and its inhibition by a glycoprotein factor Indian Journal of Experimental Biology 30 1056-1061

Barua M, Halder S and Majumder GC (1990) Occurrence of a coupled enzyme system on the intact sperm outer surface that phosphorylate and dephosphorylate ecto-proteins Biochemistry International 20 1089-1096

Bensadown A and Weinstein D (1976) Assay of proteins in the presence of interfering materials Analytical Biochemistry 70 240-250

Boman BM, Zschunke MA and Scott RE (1984) Topography of protein kinases and phosphoproteins in the plasma membrane of 3T3 cells Journal of Cellular Physiology 121 357-367

Chaudhry PS and Casillas ER (1989) Casein kinase II activity and polyamine stimulated protein phosphorylation of cytosolic and plasma membrane proteins in bovine sperm Archives of Biochemistry and Biophysics 271(1) 98-109

Cooper JA, Sefton BM and Hunter T (1983) Detection and quantitation of phosphotyrosine in proteins Methods in Enzymology 99387-402

Devi KU, Ahmad MB and Shivaji S (1997) A maturation-related differential phosphorylation of the plasma membrane proteins of the epididymal spermatozoa of the hamster by endogenous protein kinase Molecular Reproduction and Development 47341-350

Dey CS and Majumder GC (1990) Type I and II cAMP-dependent ecto protein 
kinases in goat epididymal spermatozoa and their enriched activities in forward motile spermatozoa Biochemistry and Cell Biology $68459-470$

Halder S and Majumder GC (1986) Phosphorylation of external cell-surface proteins by an endogenous ecto-protein kinase of goat epididymal intact spermatozoa Biochimica et Biophysica Acta 887 291-303

Halder S, Dey CS and Majumder GC (1986) An ecto-cyclic AMP-independent protein kinase in goat spermatozoa and its change of activity during forward motility Biochemistry International 13 809-817

Halder S, Dey CS and Majumder GC (1990) Ficoll gradient isolation of immature sperm of high purity and intactness from goat epididymis Archives of Andrology 24 125-128

Hokin LE, Sastry PS, Galsworthy PK and Yoda A (1965) Evidence that a phosphorylated intermediate in a brain transport adenosine triphosphate is an acyl phosphate Proceedings of the National Academy of Sciences USA 54 177-184

Huacuja L, Delgado NM, Merchant H, Panchardo RM and Rosado A (1977) Cyclic AMP induced incorporation of ${ }^{32} \mathrm{P}$ into human spermatozoa membrane components Biology of Reproduction 17 89-96

Kang ES and Chiang TM (1986) Characterization of the major phosphoproteins and its kinase on the surface of rat adipocyte Experimental Cell Research 167 343-359

Kinzel V and Mueller GC (1973) Phosphorylation of surface proteins of HeLa cells using an exogenous protein kinase and $\left[\gamma^{32} \mathrm{P}\right] \mathrm{ATP}$ Biochimica et Biophysica Acta 322 337-351

Laemmli UK (1970) Cleavage of structural proteins during assembly of the head of bacteriophage T4 Nature 227 680-685

Lytle C and Forbush B (1992) The Na-K-Cl cotransport protein of shark rectal gland II. Regulation by direct phosphorylation Journal of Biological Chemistry 267(35) 25438-25 443

McGuinness TL, Lai $\mathbf{Y}$ and Greengard $\mathbf{P}(1985) \mathrm{Ca}^{2+} /$ calmodulin-dependent protein kinase II Journal of Biological Chemistry 260 1696-1704

Majumder GC and Turkington RW (1972) Hormone dependent phosphorylation of ribosomal and plasma membrane proteins in mouse mammary gland in vitro. Journal of Biological Chemistry 247 7207-7217

Mitra S and Majumder GC (1991) Alteration of the ecto-protein phosphorylation profile of intact goat spermatozoa during epididymal maturation Biochemistry International 23(3) 611-618

Mitra S, Nath D and Majumder GC (1994) Purification and characterization of a protein kinase from goat sperm plasma membrane Biochemistry and Cellular Biology $\mathbf{7 2} 218-226$
Moore HDM (1979) The net negative surface charge of mammalian spermatozoa as determined by isoelectric focussing. Changes following sperm maturation, ejaculation, incubation in the female tract and after enzyme treatment International Journal of Andrology 2 244-262

Naik UP, Kornicki E and Ehrlich YA (1991) Phosphorylation and dephosphorylation of human platelet surface proteins by an ecto-protein kinase/phosphatase system Biochimica et Biophysica Acta 1092(2) 256-264

Nishizuka $Y$ (1984) The role of protein kinase $C$ in cell surface signal transduction and tumor promotion Nature (London) 308 693-697

Noland TD, Olson GC and Garbers DL (1984) Protein phosphorylation of plasma membranes from bovine epididymal spermatozoa Biology of Reproduction 31 185-194

Parks JE and Hammerstedt RH (1985) Developmental changes occurring in the lipids of ram epididymal sperm plasma membrane Biology of Reproduction 32 653-668

Rana APS and Majumder GC (1987) Factors influencing the yield and purity of goat sperm plasma membrane isolated by means of an aqueous twophase-polymer system Preparative Biochemistry 17 261-281

Rana APS and Majumder GC (1989) A two-phase-polymer method for isolation of maturing goat sperm plasma membrane Preparative Biochemistry 19(2) 167-173

Sarrouilhi D, Lalegerie P and Bandry M (1992) Endogenous phosphorylation and dephosphorylation of rat liver plasma membrane proteins suggesting a $18 \mathrm{kDa}$ phosphoprotein as a potential substrate for alkaline phosphatase Biochimica et Biophysica Acta 1118(2) 116-122

Tash JS and Means AR (1983) Cyclic adenosine 3'5'monophosphate, calcium and protein phosphorylation in flagellar motility Biology of Reproduction 28 75-104

Uno I, Veda T and Greengard P (1977) Adenosine 3'5'monophosphate regulated phosphoprotein system of neuronal membranes II. Solubilization, purification and some properties of an endogenous adenosine $3^{\prime} 5^{\prime}$ monophosphate dependent protein kinase Journal of Biological Chemistry 252 5165-5174

Ward GE and Vacquire VD (1983) Dephosphorylation of a major sperm membrane protein is induced by egg jelly during sea urchin fertilization Proceeding National Academy of Sciences USA 80 5578-5582

Yanagimachi R (1988) Mammalian fertilization. In The Physiology of Reproduction pp 189-317 Eds E Knobil, J Neil, LL Ewings, GS Greenwald, C Market and W Paff. Raven Press, New York 